\title{
THE CASE FOR EXTENDED BRIEF INTERVENTIONS
}

\author{
Nick Heather ${ }^{1}$
}

Guest Editorial

Brief interventions directed against hazardous and harmful drinking have become popular in recent years, both among researchers and, to some extent, among general practitioners and other health professionals. There is a strong evidence-base, at least in primary health care, to justify this popularity (Kaner, NewburyBirch \& Heather, 2009). But there is often confusion about what exactly alcohol brief intervention consists of. In fact, the term "brief intervention" does not describe a single, well-defined activity but rather a family of interventions that differ in a range of ways (Heather, 1995). Although they all share the characteristics of being briefer than most formal treatment programmes for alcohol problems and of being aimed at drinkers with less severe problems and levels of dependence than those typically attending specialised treatment services, brief interventions differ among themselves in duration over time, number of scheduled sessions, procedures and accompanying materials, styles of interaction, delivery personnel and settings, and the underlying theoretical approach on which they are based.

\section{Two main classes of brief intervention}

Despite this diversity, it is possible to discern two broad classes of therapeutic activity that encompass most of the actual forms of brief intervention to be found in the scientific literature and in practice; these are "brief advice" and "extended brief intervention". This distinction was incorporated in a review of the effectiveness of treatment for alcohol problems commissioned by the UK Department of Health (Raistrick, Heather \& Godfrey, 2006) and was also included in the recommendations of the National Institute for Health and Clinical Excellence in recently published guidance on the prevention of hazardous and harmful drinking in the UK (National Institute for Health and Clinical Excellence, 2010; see also Kaner, 2010). These two classes of brief intervention will now be described.

\section{Brief advice}

This type of brief intervention is also sometimes called "simple advice" or "structured brief advice", in the latter case to make the point that, to be effective, the advice in question should be delivered according to a defined form and structure and not merely as the practitioner sees fit. The main settings in which brief advice has been studied and applied are busy medical services, particularly primary health care or accident and emergency services, in which time is at a premium. Intervention usually proceeds immediately following a positive screen for hazardous or harmful drinking, although occasionally the patient is asked to return to the service to receive a brief intervention. In such time-limited and pressurised situations, the most that can be allowed for intervention is 5-10 minutes or sometimes even less.

Brief advice usually consists of a standard package involving information on drinking risk levels, the patient's own risk status in relation to those levels, encouragement to cut down and to set a date to begin, and perhaps a few simple hints on how cutting down might best be achieved, often accompanied by self-help material giving more tips on cutting down. Practitioners are often urged to adopt a style of interaction with the patient summarised by the wellknown FRAMES principles:

Feedback - provide feedback on the patient's risk for alcohol problems

Responsibility-make clear that the individual is responsible for change

Advice-advise reduction or give explicit direction to change

Menu-provide a variety of options for change

Empathy-adopt a warm, reflective and understanding approach

Self-efficacy-encourage optimism about changing behaviour

\section{Extended brief intervention}

This type of brief intervention is obviously of longer duration than brief advice and is sometimes called "brief counselling". It usually lasts between 20-40 minutes in a single session and often includes follow-up sessions. Apart from this difference, perhaps the main contrast with brief advice is the theoretical underpinning of the intervention; extended brief intervention nowadays is almost always based on the principles of motivational 
interviewing as described by Miller and Rollnick (1991, 2002). A brief form of motivational interviewing was described by Rollnick, Heather and Bell (1992) and its contents and methods have subsequently been influenced by the work of Steven Rollnick and colleagues on applying the principles and techniques of motivational interviewing to changing healthdamaging behaviour in healthcare settings (Rollnick, Mason \& Butler, 1999; Rollnick, Miller \& Butler, 2008). In contrast to brief advice, it can be considered a more refined, flexible and patient-centred approach that explicitly avoids giving advice unless specifically requested by the patient. For obvious reasons, brief motivational interviewing has usually been applied in settings and situations where there is more time for intervention and where staff trained in the approach are available. At its upper limit, brief motivational interviewing merges with Motivational Enhancement Therapy (Miller et al., 1992) and other adaptations of motivational interviewing (Burke, Arkowitz \& Dunn, 2003) given in specialist treatment settings.

Although almost all examples of extended brief intervention found in the current literature are derived from motivational interviewing, it should be noted that there exists an earlier form of extended brief intervention which might be called "condensed cognitive behaviour therapy' and which involves shorter versions of the methods that make up the cognitive-behavioural approach to treatment: identification of high-risk situations, training in ways of coping with those situations without excessive drinking, skills training in alternative behaviours, cognitive restructuring of attitudes and beliefs about self and drinking, relapse prevention techniques, etc. This kind of brief intervention was studied in the first trials in primary health care in the 1980s (Heather et al., 1987; Wallace, Cutler \& Haines, 1988) and was compared with a motivational interviewing approach by Heather and colleagues (1996). Following the enormous popularity of motivational interviewing, it is now virtually restricted to self-help manuals, often distributed without direct therapist contact. It will not be considered further here.

\section{What does the evidence tell us?}

So what is the evidence for the effectiveness of these two classes of brief intervention to support their implementation in practice? A recent Cochrane review of research in primary health care by Kaner and colleagues (2009) has confirmed the conclusions of previous systematic reviews and meta-analyses that brief advice delivered in primary health care is effective compared to control conditions. The success rate of brief advice has been calculated at between $8 \%$ and $12 \%$ (Moyer et al., 2002). While comparing favourably with the success rate for advice by physicians to quit smoking (20\%: Silagy \& Stead, 2003), some practitioners might regard this as low in clinical terms; in public health terms, however, if brief advice of this kind were consistently delivered in, for example, the great majority of general medical practices in a country and given to all those screening positive, it would lead to substantial reductions in hazardous and harmful drinking in the population at large and make a very important contribution to public health. Thus, although many individual patients will benefit, brief advice in primary health care may be thought of as a "shotgun" approach to reducing alcohol-related harm with important public health potential.

Evidence to support brief advice in other medical setting, such as accident and emergency departments (Crawford et al., 2004) and general hospital wards (Holloway et al., 2007) is promising, although still considered inconclusive (Harvard et al., 2008; McQueen et al., 2009) and research is proceeding in these settings. In addition there are a range of other settings, both medical and non-medical, for which the evidence of effectiveness of brief advice ranges from inconclusive to non-existent but where there are reasons to believe that they have potential to reduce alcohol-related harm (see, eg, Heather \& Kaner, 2010).

Given the established effectiveness of brief advice, it is clearly necessary to demonstrate that extended brief intervention offer additional benefits to patients who receive it compared with brief advice. However, the evidence on this issue is best described as mixed. Studies and observations that go against the conclusion that extended brief advice offers anything more than brief advice are as follows:

a) In the systematic review by Kaner and colleagues (2009) referred to above, there was a tendency for patients given more extended brief intervention to show greater reductions in consumption at one-year follow-up than those given shorter interventions but this difference was not statistically significant;

b) An earlier systematic review by Ballesteros et al. (2004) found no clear evidence for a "doseresponse relationship" between duration of brief intervention and outcome, meaning that there were no firm grounds for concluding that more extended interventions added to the benefits of shorter interventions; 
c) Phase II of the WHO Collaborative Study on the Identification and Management of Alcohol-related Problems in Primary Care (Babor, 1996) found that, compared with five minutes simple advice following 15 minutes of assessment, there was no added benefit of an additional 15 minutes brief counselling or of extended counselling over three more sessions.

On the other hand, evidence suggestive of an added benefit of extended brief interventions is as follows:

a) The greater reduction in consumption at followup among patients who received an extended brief intervention in the Kaner and colleagues meta-analysis (see above) approached statistical significance $(p=0.09)$ and may reflect a Type 2 error, ie, accepting the hypothesis of no difference between groups when it is in fact false;

b) In the WHO Collaborative Study (see above), there was an interesting interaction in the data such that simple advice was more beneficial among men who recognised a recent alcohol-related problem and extended brief intervention was more effective among men who did not recognise a recent problem, suggesting that the latter worked better for patients who did not readily accept the need for change;

c) Some studies and reviews have reported increased benefits of extended brief interventions over brief advice (eg, Richmond et al., 1995; Israel et al., 1996; Poikolainen, 1999);

d) An analysis by Berglund (2005) of data collected by the Swedish Technology Assessment (Berglund, Thelander \& Jonsson, 2003) showed that, compared with a robust and stable effect of singlesession brief interventions, those with repeat sessions demonstrated a larger average effect but one which was not uniform across studies;

e) Most of the "classic" trials of brief intervention in the older literature (eg, Wallace, Cutler \& Haines, Anderson \& Scott, 1992; Fleming et al., 1997) studied interventions that could only be described as extended according to the description given above. These all showed a clear benefit of intervention compared with non-intervention controls or treatment as usual but did not include another control group consisting of briefer or simple advice. Thus, although the additional benefits of extended brief interventions cannot be deduced from these studies, they do represent prima facie evidence that brief interventions are effective;

f) Finally, for brief interventions delivered to heavy drinking students in educational establishments in the USA, there is clear evidence from a large number of studies of the effectiveness of extended brief interventions based on motivational interviewing principles (Carey et al., 2007).

\section{Implications for practice}

Given the evidence reviewed above, one conclusion might be that only brief advice should be implemented in practice at the present time; if and when evidence for the extra benefits of extended brief intervention becomes stronger, this view would say, implementation could be considered at that time. This certainly seems to have been the view of Anderson and Baumberg (2006) in their report to the European Commission on alcohol and alcohol policy in Europe. "Brief physician advice' was included in a recommended package of effective policies and programmes for implementation in the European Union. The recommendation in respect of brief advice was based on World Health Organisation modelling of the impact and cost of providing primarycare based brief advice to $25 \%$ of the at-risk population; applying this to the European Union would avoid an estimated 408,000 years of disability and premature death at a cost of 740 million Euros per year. It was noted that brief intervention for hazardous and harmful drinking, in the form of physician brief advice, was one of the most cost-effective of all health service interventions in promoting health gains. However, there was no mention in the report of brief counselling, brief motivational interviewing or any other form of more extended brief intervention beyond brief advice.

The argument for widespread implementation of brief advice by physicians made by Anderson and Baumberg is compelling, especially on the grounds of cost-effective harm prevention. But could there yet be a current role for extended brief intervention in a recommended package of measures to prevent alcohol-related harm? Are there circumstances in which it is justifiable to implement extended brief interventions in practice? There are reasons for believing so and this was also the view of the NICE guidance referred to above (National Institute for Health \& Clinical Excellence, 2010). These reasons are as follows:

i. First and most obviously, having been given brief advice some patients will request more discussion of their drinking with a health professional. Such a request is best served by brief motivational interviewing to explore what obstacles stand in the way of an attempt by the patient to cut down drinking to less risky levels. 
ii. The clinician may also judge that the seriousness of the patient's alcohol problem requires more than just brief advice. Although practice should be based on evidence, there will always be place for clinical judgement too and it is likely that some health professionals would object to offering nothing more than brief advice to all the problem drinkers presenting to them.

iii. Some patients, probably the majority, will not respond to brief advice on follow-up and, in some cases, the offer of more extended brief intervention could be judged appropriate. This would be part of a stepped care model in which successively more intensive levels of intervention are tried if previous levels have proved unsuccessful (see Raistrick, Heather \& Godfrey, 2006).

iv. Extended brief interventions might also be given to young people aged 16-17 with alcohol-related difficulties (National Institute for Health \& Clinical Excellence, 2010). Many would consider the offer of brief advice here to be inappropriate because young people of that age are not well-known for accepting advice! In addition, the evidence from educational establishments shows that brief motivational interviewing is appropriate and effective in the age -range.

v. In a manual on the use of brief interventions for hazardous and harmful drinking issued by the World Health Organisation (Babor \& HigginsBiddle, 2001), "brief counselling' based on the stages of change model (Prochaska \& DiClemente, 1986 ) is explicitly recommended for patient who score between 16 and 19 inclusive on the Alcohol Use Disorders Identification Test (AUDIT: Saunders et al., 1993).

vi. Brief motivational interviewing is ideally suited to individuals who are ambivalent about the need to cut down their drinking - in other words, those who are in the Contemplation stage of the stages of change model (Prochaska \& DiClemente, 1986). As noted above, there is some evidence from the Phase II study of the WHO Collaborative Project (Babor, 1996) that brief counselling is especially suited to patients who are not ready to cut down drinking and the effectiveness of brief motivational interviewing among such patients was shown by Heather and colleagues (1996). In addition, there is very good evidence for the effectiveness of motivational interviewing in the treatment of behavioural disorders in general (Lundhal et al., 2010).
None of these reasons should be taken as arguments against the deployment of brief advice in primary health care and other settings. On the contrary, the position here is that brief advice should always be offered as a first step to all patients who screen positive or who are otherwise judged to be hazardous or harmful drinkers. This is because the evidence firmly indicates that this is an effective and cost-effective policy and that, as noted above, it could make a considerable contribution to public health. It is only as an adjunct or addition to brief advice, in the circumstances outlined above, that the implementation of extended brief intervention is argued for here.

\section{Implications for research}

It is clear that the case for extended brief interventions that which has been made in this article is not based firmly on evidence of effectiveness, which it has been conceded is mixed, but on pragmatic grounds of everyday practice and patient need. As such, it is vulnerable to counter-arguments and other points of view.

There is one recommendation, however, that seems incontrovertible. This is the need for further research on this issue. Ironically, a comparison of brief advice and more extended brief intervention was included in the first trial of brief intervention in general medical practice which began almost 30 years ago (Heather et al., 1987); unfortunately that trial was under-funded and under-powered to provide a proper test of the relative effectiveness of the two approaches. Since that, time, despite a few relevant findings that have been mentioned earlier in the article, the issue has been largely ignored.

It is now time that this issue was taken very seriously by researchers and investigated in a proper manner. Assuming the additional benefits of extended brief interventions will not apply to all patients on all occasions, we need to know for what kinds of problem excessive drinker and in what kinds of settings and circumstances, if any, those benefits do apply. The findings of the Screening and Intervention Programme for Sensible Drinking (SIPS) in England (Coulton et al., 2009; Kaner et al., 2009; Newbury-Birch et al., 2009), which will be available during 2011 , may be able to clarify this issue.

\section{References}

1. Anderson, P., \& Baumberg, B. (2006). Alcohol in Europe: A Public Health Perspective - A Report for the European Commission. London: Institute of Alcohol Studies. 
2. Anderson, P., \& Scott, E. (1992). The effect of general practitioners' advice to heavy drinking men. British Journal of Addiction, 87, 891-900.

3. Babor, T. F. (1996). A cross-national trial of brief interventions with heavy drinkers. American Journal of Public Health, 86, 948-955.

4. Babor, T., \& Higgins-Biddle, J. (2001). Brief Intervention for Hazardous and Harmful Drinking. Geneva, Switzerland: World Health Organisation.

5. Ballesteros, J., Duffy, J. C., Querejeta, I., Arino, J., \& GonzalezPinto, A. (2004). Efficacy of brief interventions for hazarous drinkers in primary cared: systematic review and meta-analysis. Alcoholism: Clinical \& Experimental Research, 28(4), 608618.

6. Burke, B. L., Arkowitz, H., \& Dunn, C. (2002). The efficacy of motivational interviewing and its adaptations: what we know so far. In W. R. Miller \& S. Rollnick (Eds.), Motivational Interviewing: Preparing People for Change (2nd ed., pp. 217-250). New York NY: Guilford.

7. Carey, K., Scott-Sheldon, L., Carey, M., \& DeMartini, K. (2007). Individual-level interventions to reduce college student drinking: a meta-analytic review. Addictive Behaviors, 32, 2469-2494.

8. Coulton, S., Perryman, K., Bland, M., Cassidy, P., Crawford, M., DeLuca, P., et al. (2009). Screening and brief interventions for hazardous alcohol use in accident and emergency departments: a randomised controlled trial protocol. BMC Health Services Research, 9, 114.

9. Crawford, M. J., Patton, R., Touquet, R., Drummond, C., Byford, S., Barrett, B., et al. (2004). Screening and referral for brief intervention of alcohol-misusing patients in an emergency department: a pragmatic randomised controlled trial. Lancet, 364, 1334-1339.

10. Fleming, M. F., Barry, K. L., Manwell, L. B., Johnson, K., \& London, R. (1997). Brief physician advice for problem alcohol drinkers: a randomized controlled trial in community-based primary care practices. Journal of the American Medical Association, 277, 1039-1045.

11. Harvard, A., Shakeshaft, A. P., \& Sanson-Fisher, R. (2008). Systematic review and meta-analysis of strategies targeting alcohol problems in emergency departments: interventions to reduce alcohol-related injuries. Addiction, 103, 368-376.

12. Heather, N. (1995). Interpreting the evidence on brief interventions for excessive drinkers: the need for caution. Alcohol \& Alcoholism, 30, 287-296.

13. Heather, N. \& Kaner, E. (2010) (Eds.) Special Issue on Alcohol Brief Interventions: Breaking New Ground. Drug \& Alcohol Review, 29, 581-688.

14. Heather, N., Campion, P. D., Neville, R. G., \& MacCabe, D. (1987). Evaluation of a controlled drinking minimal intervention for problem drinkers in general practice (The DRAMS Scheme). Journal of the Royal College of General Practitioners, 37, 358363.

15. Heather, N., Rollnick, S., Bell, A., \& Richmond, R. (1996). Effectiveness of brief counselling among male heavy drinkers identified on general hospital wards. Drug and Alcohol Review, 15, 29-38.

16. Holloway, A., Watson, H., Arthur, A., Starr, G., McFadyen, A., \& McIntosh, J. (2007). The effect of brief intervention on alcohhol consumption among heavy drinkers in a general hospital setting. Addiction, 102, 1762-1770.

17. Israel, Y., Hollander, O., Sanchez-Craig, M., Booker, S., Miller, V., Gingrich, R., et al. (1996). Screening for problem drinking and counseling by the primary care physician-nurse team. Alcoholism, Clinical \& Experimental Research, 20(8), 14431450 .
18. Kaner, E. (2010). NICE work if you can get it: development of national guidance incorporating screening and brief intervention to prevent hazardous and harmful drinking in England. Drug \& Alcohol Review, 29, 589-595.

19. Kaner, E., Bland, M., Cassidy, P., Coulton, S., Crawford, M., DeLuca, P., et al. (2009). Screening and brief interventions for hazardous and harmful alcohol use in primary care: a randomised controlled trial protocol. BMC Public Health, 9, 287.

20. Kaner, E., Dickinson, H., Beyer, F., Pienaar, E., Schlesinger, C., Campbell, F., et al. (2009). The effectiveness of brief alcohol interventions in primary care settings: a systematic review. Drug \& Alcohol Review, 28, 301-323.

21. Kaner, E., Newbury-Birch, D., \& Heather, N. (2009). Brief intervention. In P. Miller (Ed.), Evidence-based Addiction Treatment (pp. 189-213). Burlington VT: Academic Press.

22. Lundhal, B., Kunz, C., Brownell, C., Tollefson, D., \& Burke, B. (2010). A meta-analysis of motivational interviewing: twenty-five years of empirical studies. Research on Social Work Practice, 20, 137-160.

23. McQueen, J., Howe, T., Allan, L., \& Mains, D. (2009). Brief interventions for heavy alcohol users admitted to general hospital wards. Cochrane Review. Chichester: Wiley.

24. Miller, W. R., \& Rollnick, S. (1991). Motivational Interviewing: Preparing People to Change Addictive Behavior. New York NY: Guilford.

25. Miller, W. R., \& Rollnick, S. (2002). Motivational Interviewing: Preparing People for Change (2nd ed.). New York NY: Guilford.

26. Miller, W., Zweben, A., DiClemente, C., \& Rychtarik, R. (1992) Motivational Enhancement Therapy Manual: A Clinical Guide for Therapists Treating Individuals with Alcohol Abuse and Dependence. Rockville MD: Alcohol, Drug Abuse \& Mental Health Administration, US Department of Health \& Human Services

27. Moyer, A., Finney, J., Swearingen, C., \& Vergun, P. (2002). Brief Interventions for alcohol problems: a meta-analytic review of controlled investigations in treatment -seeking and nontreatment seeking populations. Addiction, 97, 279-292.

28. National Institute for Health and Clinical Excellence. (2010). Alcohol Use Disorders: Preventing the Development of Hazardous and Harmful Drinking (No. Nice Public Health Guidance 24). London: Author.

29. Newbury-Birch, D., Bland, M., Cassidy, P., Coulton, S., Deluca, P., Drummond, C., et al. (2009). Screening and brief interventions for hazardous and harmful alcohol use in probation services: a cluster randomised controlled trial protocol. BMC Public Health, 9, 418.

30. Poikolainen, K. (1999). Effectiveness of brief interventions to reduce alcohol intake in primary health care populations: a meta-analysis. Preventive Medicine, 28, 503-509.

31. Prochaska, J., \& DiClemente, C. C. (1986). Towards a comprehensive model of change. In W. Miller \& N. Heather (Eds.), Treating Addictive Behaviours: Processes of Change (pp. 3-27). New York: Plenum Press.

32. Raistrick, D., Heather, N., \& Godfrey, C. (2006). Review of the Effectiveness of Treatment for Alcohol Problems. London: National Treatment Agency.

33. Richmond, R., Heather, N., Wodak, A., Kehoe, L., \& Webster, I. (1995). Controlled evaluation of a general practice-based brief intervention for excessive drinking. Addiction, 90, 119-132.

34. Rollnick, S., Heather, N., \& Bell, A. (1992). Negotiating behaviour change in medical settings: the development of brief motivational interviewing. Journal of Mental Health, 1, 25-37.

35. Rollnick, S., Mason, P., \& Butler, C. (1999). Health Behavior Change: A Guide for Practitioners. Edinburgh: Churchil Livingstone. 
36. Rollnick, S., Miller, W., \& Butler, C. (2008). Motivational Interviewing in Health Care: Helping Patients Change. New York: Guilford Press.

37. Saunders, J. B., Aasland, O. G., Babor, T. F., de la Fuente, J. R., \& Grant, M. (1993). Development of the Alcohol Use Disorders Identification Test (AUDIT):WHO Collaborative Project on Early
Detection of Persons with Harmful Alcohol Consumption--II. Addiction, 88(6), 791-804.

38. Silagy, C., \& Stead, L. (2003). Physician advice for smoking cessation (Cochrane Review). Chichester: Wiley.

39. Wallace, P., Cutler, S., \& Haines, A. (1988). Randomized controlled trial of general practitioner intervention with excessive alcohol consumption. British Medical Journal, 297, 663-668. 


\section{RAZLOGI ZA UPORABO KRATKIH INTERVENCIJ}

Nick Heather ${ }^{1}$

Uvodnik

V zadnjih letih se kratke intervencije zaradi tveganega in škodljivega uživanja alkohola vedno bolj uveljavljajo, tako med raziskovalci, kot delno tudi med splošnimi zdravniki in drugimi zdravstvenimi delavci. To povečano zanimanje za ta ukrep, vsaj na primarni ravni, je močno podprto z dokazi o njegovi učinkovitosti (Kaner, Newbury-Birch\&Heather, 2009). Pogosto pa ni povsem jasno, kaj natančno predstavlja kratka intervencija zaradi pitja alkohola. Dejstvo je, da izraz »kratka intervencija « ne opisuje enkratne, natančno določene storitve, temveč se nanaša na skupino posegov, ki se med seboj razlikujejo (Heather,1995). Čeprav je vsem kratkim intervencijam skupno to, da so krajše kot večina uveljavljenih programov zdravljenja težav z alkoholom, in so namenjene obravnavi pivcev, ki imajo manj resne težave in so manj odvisni od alkohola kot posamezniki vključeni v specializirane programe zdravljenja, se kratke intervencije razlikujejo med seboj v trajanju, številu obravnav, v postopkih in uporabljenih materialih, oblikah terapevtske interakcije, izvajalcev in okolja ter v teoretičnem pristopu na katerem temeljijo.

\section{Dve glavni skupini kratkih intervencij}

Kljub razlikam, lahko govorimo o dveh večjih skupinah terapevtskih obravnav, kamor sodi večina oblik kratkih intervencij, ki jih srečamo v strokovni literaturi in $v$ praksi. Gre za tako imenovane »kratke nasvete in »razširjene kratke intervencije «. O tem razlikovanju je govora v pregledu učinkovitosti zdravljenja težav z alkoholom, ki ga je naročil Oddelek za zdravstvo Velike Britanije (UK Department of Health) (Raistric; Heather \& Godfrey, 2006) in v priporočilih nacionalnega inštituta za zdravje in klinično odličnost v nedavno objavljenih smernicah za preprečevanje tveganega in škodljivega uživanja alkohola v Veliki Britaniji (National Institute for Health and Clinical Excellence, 2010; glej še Kaner, 2010). V nadaljevanju opisujemo ti dve skupini kratkih intervencij.

\section{Kratki nasvet}

To vrsto kratke intervencije včasih imenujemo tudi »enostavni nasvet« ali "strukturirani kratki nasvet«, to pa zato, ker ni dovolj, da zdravnik nasvet posreduje kot se mu zdi najbolj primerno, temveč mora - če naj bo učinkovit - upoštevati določeno obliko in strukturo. Kratke nasvete so preučevali in uporabljali v glavnem v zelo dejavnih zdravstvenih okoljih, predvsem $v$ primarnem zdravstvenem varstvu in na urgentnih oddelkih, kjer je čas zelo dragocen. Intervencija običajno neposredno sledi oceni, da gre pri posamezniku za tvegano in škodljivo uživanje alkohola. Včasih pacientu predlagamo, naj se po kratko intervencijo vrne v ustanovo. V teh okoljih, kjer poteka delo pod časovnim pritiskom, lahko intervenciji namenimo le pet do deset minut, včasih celo manj. Kratki nasvet navadno obsega standardni sveženj informacij o stopnjah tveganja pri uživanju alkohola in o statusu bolnika glede na te stopnje tveganja, vsebuje pa tudi spodbudo za zmanjšanje porabe alkohola in časovno opredelitev začetka te spremembe. Sem sodi še nekaj enostavnih napotkov za uspešno zmanjšanje uživanja alkohola in priročniki za samopomoč z dodatnimi nasveti. Zdravniki morajo pogosto uporabiti način interakcije z bolnikom, ki ga na kratko povzemajo znana načela FRAMES (Feedback-ResponsibilityAdvice-Menu-Empathy).

Povratna informacija - pridobitev povratne informacije o bolnikovem tveganju za težave z alkoholom;

Odgovornost - jasna informacija o tem, da je posameznik sam odgovoren za spremembe;

Nasvet - nasvet za zmanjšanje uživanja alkohola ali jasno navodilo za spremembo;

Izbor - ponudba različnih možnosti za doseganje sprememb vedenja;

Empatija - topel odnos do bolnika in izražanje razumevanja do njegovih težav;

Samoučinkovitost - spodbujanje optimističnega pogleda na vedenjske spremembe.

\section{Razširjena kratka intervencija}

Ta vrsta kratke intervencije je seveda daljša od kratkega nasveta in jo imenujemo tudi »kratko svetovanje«. Običajno traja ena obravnava 20 do 40 minut, večkrat pa ji sledijo še kontrolna srečanja. Od kratkega nasveta se razlikuje predvsem po teoretični osnovi intervencije. Razširjena kratka intervencija, ki jo uporabljamo danes, skoraj vedno temelji na načelih 
motivacijskega pogovora, kot ga opisujeta Miller in Rollinck (1991, 2002). Rollinck, Heather in Bell (1992) so opisali krajšo obliko motivacijskega pogovora, na vsebino in uporabljene metode pa so pozneje vplivale študije Stevena Rollincka in sodelavcev o uporabi načel in tehnik motivacijskega pogovora pri spreminjanju tveganega vedenja $v$ zdravstvenih ustanovah (Rollinck, Mason \& Butler, 1999; Rollinck, Miller \& Butler, 2008). Za razliko od kratkega nasveta, gre tu za izpopolnjen, prožen in k bolniku usmerjen pristop, pri katerem se dosledno izogibamo dajanju nasvetov, razen $v$ primeru, da zanje zaprosi bolnik sam. Seveda je zato kratki motivacijski pogovor $v$ rabi $v$ tistih okoljih in situacijah, kjer je za intervencijo več časa in so na voljo izvajalci izurjeni v tej tehniki.V svoji skrajni obliki kratki motivacijski pogovor prehaja $v$ terapijo za spodbujanje motivacije (Motivational Enhancement Therapy) (Miller in sod., 1992) in v druge oblike motivacijskega pogovora (Burke, Arkowitz \& Dunn, 2003), ki potekajo v specializiranih terapevtskih ustanovah.

Čeprav skoraj vsi primeri razširjenih kratkih intervencij, opisani v literaturi, izhajajo iz motivacijskega pogovora, je treba opozoriti na to, da obstaja tudi zgodnejša oblika razširjene kratke intervencije, ki bi jo lahko poimenovali "zgoščena kognitivna behavioristična terapija «. Ta obsega krajše oblike metod, ki sestavljajo kognitivnobehavioristični pristop k zdravljenju: opredelitev situacij $z$ visokim tveganjem, učenje strategij za obvladovanje teh situacij brez pretiranega pitja alkohola, učenje veščin za alternativne oblike vedenja, kognitivno restrukturiranje prepričanja in odnosa do sebe in pitja alkohola; tehnike za preprečevanje relapsov itd. Te vrste kratkih intervencij so preučevali v prvih študijah na primarni zdravstveni ravni $v$ 80-ih letih prejšnjega stoletja (Heather in sod., 1987; Wallace, Cutler \& Haines, 1988) in jo primerjali z motivacijskim pogovorom (Heather in sod., 1996). Po obdobju izrednega zanimanja za motivacijski pogovor, je njegova uporaba danes omejena le še na priročnike za samopomoč, ki jih večkrat dobijo posamezniki brez neposrednega stika s terapevtom. Tega pristopa $v$ nadaljevanju ne bomo obravnavali.

\section{Kaj nam govore dokazi?}

Kakšni so torej dokazi o učinkovitosti teh dveh skupin kratkih intervencij, ki naj bi podprli njihovo uporabo $v$ praksi? Pregledna študija raziskav na primarni ravni, ki jo je nedavno objavil Kaner s sodelavci (2009), je potrdila ugotovitve prejšnjih sistematičnih ocen in meta analiz o uspešnosti kratkih nasvetov na primarni ravni $v$ primerjavi s kontrolnimi primeri, t.j. $z$ uporabo tega pristopa pri drugih težavah. Ugotovili so, da je uspešnost kratkega nasveta 8 do 12 odstotna (Moyer in sod., 2002). Čeprav je odstotek ugoden $v$ primerjavi z ocenjeno uspešnostjo nasvetov, ki jih dajejo zdravniki za opustitev kajenja (20\%; Silagy \& Stead, 2003) se nekaterim zdravnikom morda zdi, da je v kliničnem smislu dokaj nizek. S stališča javnega zdravstva pa ugotavljamo, da bi ta pristop lahko v veliki meri zmanjšal tvegano in škodljivo uživanje alkohola med splošnim prebivalstvom in tako bistveno prispevali $\mathrm{k}$ boljšemu javnemu zdravju, če bi bili $v$ večini ustanov primarnega zdravstva vsi posamezniki s potrjeno diagnozo tveganega pitja dosledno deležni teh nasvetov. Ob tem, da je kratki nasvet koristen za mnoge posameznike, na primarni zdravstveni ravni nanj lahko gledamo kot na »udarni« ukrep za zmanjševanje škode, ki jo povzroča alkohol, z velikimi obeti za javno zdravstvo.

Dokazi v prid uporabi kratkega nasveta $v$ drugih zdravstvenih ustanovah, kot so oddelki za poškodbe in urgentno medicino (Crawford in sod., 2004) in oddelki splošnih bolnišnic (Hallowey in sod., 2007), so obetavni, čeprav nekateri menijo, da so še nezadostni (Harvard in sod., 2008, McQueen in sod., 2009). Nadaljnje raziskave $v$ teh okoljih so še $v$ teku. Dokazi o učinkovitost kratkega nasveta $v$ drugih zdravstvenih in nezdravstvenih okoljih so pomanjkljivi oziroma jih sploh ni, vendar kljub temu obstajajo razlogi za to, da verjamemo $v$ vlogo teh ukrepov pri zmanjševanju škode, ki jo povzroči uživanje alkohola (Heather \& Kaner, 2010).

Glede na ugotovljeno učinkovitost kratkega nasveta, je treba ugotoviti, katere dodatne koristi, prinaša bolniku razširjeni kratki pogovor v primerjavi s kratkim nasvetom.

Dokaze v prid razširjenemu kratkemu pogovoru lahko najbolje opišemo kot neenotne.

Spodaj naštete raziskave nasprotujejo mnenju, da lahko razširjeni kratki nasvet ponudi bolniku več kot kratki nasvet.

a) V sistematični pregledni študiji tega področja, je Kaner s sodelavci (2009) ob enoletnem kontrolnem pregledu ugotovil, da se je uživanje alkohola bolj zmanjšalo pri tistih bolnikih, ki so bili deležni več razširjenih kratkih ukrepov kot pri tistih, ki so dobili le kratke nasvete, vendar razlika med skupinama ni bila statistično pomembna.

b) V zgodnejši sistematični raziskavi (2004) Ballesteros in sodelavci niso našli trdnih dokazov za »povezavo med odmerkom in odzivom «, med trajanjem kratke intervencije in izidom, kar kaže na to, da ni osnove za trditev, da so daljše intervencije bolj učinkovite kot krajše. 
c) $\mathrm{V}$ drugi fazi skupne raziskave SZO o prepoznavanju in obravnavi težav povezanih z alkoholom $v$ primarnem zdravstvu (WHO Collaborative Study on the Identification and Management of Alcoholrelated Problems in Primary Care ) (Babor, 1996) so ugotovili, da ukrepi , kot je podaljšanje petminutnega enostavnega nasveta, ki je sledil petnajstminutni opredelitvi težave za dodatnih petnajst minut, oziroma razširitev svetovanja na tri obravnave, bolniku niso prinesli nobenih dodatnih koristi.

Po drugi strani pa obstajajo tudi dokazi o tem, da so razširjene kratke intervencije bolj uspešne.

a) Rezultati meta analize Kranerja in sodelavcev(glej zgoraj), ki so pokazali, da se je ob enoletnem kontrolnem pregledu uživanje alkohola bolj zmanjšalo pri posameznikih, ki so bili deležni razširjenih kratkih intervencij, so se približali statistični pomembnosti $(p=0.09)$ in lahko odražajo napako tipa 2, kar pomeni, da sprejmemo hipotezo, da med skupinama ni razlike, kadar je ta $v$ resnici lažna.

b) Zgoraj omenjena skupna raziskava SZO je pokazala, da je bil enostavni nasvet bolj uspešen pri moških, ki so prepoznali svoje nedavne težave povezane s pitjem alkohola, razširjena kratka intervencija pa med tistimi, ki te težave niso priznavali. Te ugotovitve kažejo, da je slednji ukrep bolj učinkovit pri tistih posameznikih, ki težko priznajo potrebo po spremembah vedenja.

c) Nekatere raziskave in pregledne študije kažejo, da so razširjene kratke intervencije bolj učinkovite kot kratki nasveti (npr. Richmond in sod.,1995; Israel in sod.,1996, Poikolainen, 1999).

d) Berglund (2005), ki je analiziral podatke švedske tehnološke evalvacije (Swedish Technology Assessment) (Berglund, Thelander \& Jonsson, 2003), poroča, da je bil, v primerjavi z močnim stabilnim učinkom kratkih enkratnih obravnav, poprečni učinek večkratnih obravnav večji, vendar ni bil enak v vseh študijah.

e) Večina »klasičnih « raziskav v starejši literaturi (npr. Wallace, Cutler \& Haines, Anderson \& Scott,1992, Fleming in sod., 1997) je preučevala intervencije, ki jih glede na zgornji opis lahko opredelimo kot razširjene. Vse te raziskave so jasno potrdile prednosti, ki jih imajo intervencije $\mathrm{v}$ primerjavi $\mathrm{s}$ običajnimi obravnavami, vendar pa študije niso vključevale še druge kontrolne skupine, ki bi predstavljala krajše ali enostavne nasvete. Zato na osnovi izsledkov teh študij ne moremo sklepati, da imajo razširjene kratke intervencije dodatne učinke, vendar predstavljajo t.i. dokaz prima facie o uspešnosti kratkih intervencij. f) Številne študije kratkih intervencij pri študentih na izobraževalnih ustanovah v ZDA, ki so čezmerno uživali alkohol, jasno potrjujejo učinkovitost razširjenih kratkih intervencij, ki temelje na načelih motivacijskega pogovora (Carey in sod., 2007).

\section{Pomen za prakso}

Na osnovi pregledanih dokazov lahko zaključimo, da je danes v praksi uporaben le kratki nasvet. Razširjeni kratki pogovor pa naj bi začeli uporabljati takrat, ko bo zbranih več dokazov za to, da ima ta ukrep še dodatne prednosti za bolnika. Takšno je tudi mnenje Andersona in Baumberga (2006), ki sta ga v svojem poročilu predstavila Evropski komisiji za alkohol in alkoholno politiko v Evropi (European Commission on Alcohol and Alcohol policy in Europe) »Kratki nasvet zdravnika« so vključili v priporočeni sveženj učinkovitih ukrepov in programov, ki naj bi jih izvajali v EU. Priporočilo v zvezi s kratkim nasvetom je temeljilo na modeliranju vpliva in stroškov kratkih nasvetov, ki bi jih na primarni ravni nudili 25 odstotkom ogroženih prebivalcev. Po ocenah bi v EU s temi ukrepi prihranili 408,000 let invalidnosti in prezgodnjih smrti za ceno 740 milijonov evrov na leto. Ugotovili so, da je kratka intervencija pri tveganem in škodljivem uživanju alkohola $v$ obliki kratkega nasveta zdravnika eden stroškovno najbolj učinkovitih zdravstvenih ukrepov v skrbi za boljše zdravje. Poročilo pa razen kratkega nasveta ne obravnava drugih ukrepov, kot so to, kratko svetovanje, kratek motivacijski pogovor ali kakšna druga oblika razširjene kratke intervencije.

Razlogi za priljubljenost zdravnikovega kratkega nasveta, ki jih predstavljata Anderson in Baumberg, so zelo prepričljivi, še zlasti z vidika stroškovne učinkovitosti ukrepov za preprečevanja škode. Sprašujemo pa se, če je v priporočenem svežnju ukrepov za preprečevanje škode, ki jo povzroča pitje alkoholnih pijač, morda prostor tudi za razširjeno kratko intervencijo? Ali obstajajo okoliščine, v katerih je upravičena uporaba razširjenih kratkih intervencij v praksi? Obstajajo razlogi, ki govorijo temu v prid in o njih je govora tudi v zgoraj omenjenih smernicah NICE (National Institute for Health\&Clinical Excellence, 2010). Ti razlogi so naslednji:

1. Prvi in najbolj očiten razlog je v tem, da po kratkem nasvetu nekateri posamezniki zaprosijo še za dodatni pogovor o svojem pitju z zdravstvenim strokovnjakom. Tej želji najlaže ustrežemo s kratkim motivacijskim pogovorom, v katerem raziščemo na kakšne ovire naleti posameznik ko skuša zmanjšati uživanje alkohola na manj tvegano stopnjo. 
2. Zdravnik lahko presodi, da resnost težav, ki jih ima bolnik z alkoholom, zahteva več kot le kratki nasvet. Čeprav mora praksa temeljiti na dokazih, bo vedno pomembna tudi klinična presoja in nekaterim zdravstvenim delavcev se ne zdi prav, da bi vsem problematičnim pivcem, ki pridejo $\mathrm{k}$ njim, ponudili zgolj kratki nasvet.

3. Pri nekaterih bolnikih, verjetno pri večini, ob kontrolnem srečanju ne ugotavljamo nobene reakcije na kratki nasvet in zato se nam zdi v določenih primerih primerno ponuditi tem posameznikom še razširjeni kratki pogovor. Ta pogovor je sestavni del stopnjujočega se modela obravnave, kjer se intenziteta veča $z$ vsakim naslednjim ukrepom, če se izkaže, da prejšnje stopnje obravnave niso bile uspešne (Raistrick, Heather in Godfrey, 2006).

4. Razširjene kratke intervencije so primerne tudi za mladostnike $s$ težavami povezanimi s pitjem alkohola, stare od 16 do 17 let (National Institute for Health and Clinical Excellence, 2001). Mnogim se ta možnost morda ne zdi primerna, saj mladi pri teh letih niso ravno znani po dojemljivosti za nasvete! Podatki iz izobraževalnih ustanov kažejo, da je kratki motivacijski pogovor primeren in učinkovit za to starostno skupino.

5. V priročniku o uporabi kratkih intervencij $v$ obravnavi tveganega in škodljivega pitja alkoholnih pijač, ki ga je izdala SZO (Babor \& Higgins-Biddle, 2001), «kratko svetovanje«, ki temelji na stopnjah modela sprememb avtorjev Prochaske in DiClementeja (1986) še posebej priporočajo pri bolnikih, ki z vprašalnikom za samooceno o pitju alkoholnih pijač AUDIT zberejo 16 do 19 točk (Alcohol Use Disorders Identification Test; Saunders in sod., 1993).

6. Kratko motivacijsko svetovanje je idealna oblika obravnave pri posameznikih, ki so razdvojeni glede nujnosti, da omejijo svoje pitje alkohola, z drugimi besedami, pri tistih, ki so na stopnji premisleka na modelu sprememb (Prochaska in DiClemente, 1986). Zgoraj omenjena druga faza skupne raziskave SZO (Babor, 1996) je potrdila, da je kratko svetovanje še zlasti primerno pri tistih posameznikih, ki še niso pripravljeni omejiti pitja. O učinkovitosti kratkega motivacijskega pogovora pri teh bolnikih poroča Heather s sodelavci (1996). Poleg tega, so zbrani zelo trdni dokazi za uspešnost motivacijskega pogovora pri obravnavi vedenjskih motenj na splošno (Lundhal in sod., 2010).

Nobenega od teh razlogov ne moremo obravnavati kot argument proti uporabi kratkega nasveta $v$ primarnem zdravstvenem varstvu in v drugih okoljih. Prav nasprotno, mnenja smo, da moramo kratki nasvet vedno ponuditi kot prvi ukrep vsem bolnikom s potrjeno anamnezo tveganega pitja, oziroma vsem tistim, za katere sodimo, da uživajo alkohol na tvegan in škodljiv način. Z gotovostjo so dokazali, da je ta oblika obravnave uspešna in stroškovno učinkovita in da lahko z njeno pomočjo, kot smo že omenili, bistveno prispevamo $\mathrm{k}$ boljšemu javnemu zdravju. Seveda zagovarjamo razširjeno kratko intervencijo le kot dodatek k kratkemu nasvetu v zgoraj opisanih okoliščinah.

\section{Pomen za raziskave}

Jasno je, da podpora razširjeni kratki intervenciji v tem prispevku ne temelji na dokazih o njeni učinkovitosti. Priznati je treba, da ni enotnih rezultatov o uspešnosti tega ukrepa, govorimo lahko le o pragmatičnih ugotovitvah vsakodnevne prakse in o potrebah bolnikov. Ta podpora je zato seveda občutljiva za protidokaze in vsa drugačna stališča.

Dejstvo, ki mu ni moč ugovarjati, pa je potreba po nadaljnjih raziskavah na tem področju. Zanimivo je, da je bila primerjava med kratkim nasvetom in razširjeno kratko intervencijo vključena že $v$ prvi preskus kratke intervencije $v$ splošnem zdravstvene varstvu pred skoraj 30 leti (Heather in sod., 1987). Zaradi nezadostnih finančnih in kadrovskih možnosti preskusa učinkovitosti obeh oblik ukrepov na žalost ni bilo mogoče ustrezno izpeljati. Kljub nekaterim pomembnim izsledkom, ki smo jih v prispevku že omenili, pravega zanimanja za to področje vse od takrat ni bilo več.

Čas je, da se začnejo resne in prave raziskave o tem vprašanju. Ker domnevamo, da razširjeni kratki ukrepi nimajo dodatnih koristnih učinkov na vse bolnike in v vseh okoliščinah, moramo vedeti pri katerih problematičnih pivcih, $v$ katerih okoljih in v kakšnih okoliščinah, če sploh, te pozitivne učinke lahko pričakujemo. Izsledki raziskave o presejanju in intervencijah za razumno uživanje alkohola (Screening and Intervention Programme for Sensible Drinking, SIPS, Coulton in sod., 2009; Kaner in sod., 2009; Newbury-Birch in sod., 2009), ki bodo na voljo leta 2011, bodo lahko pojasnili to vprašanje.

\section{Literatura}

1. Anderson, P., \& Baumberg, B. (2006). Alcohol in Europe: A Public Health Perspective - A Report for the European Commission. London: Institute of Alcohol Studies.

2. Anderson, P., \& Scott, E. (1992). The effect of general practitioners' advice to heavy drinking men. British Journal of Addiction, 87, 891-900.

3. Babor, T. F. (1996). A cross-national trial of brief interventions with heavy drinkers. American Journal of Public Health, 86, 948-955. 
4. Babor, T., \& Higgins-Biddle, J. (2001). Brief Intervention for Hazardous and Harmful Drinking. Geneva, Switzerland: World Health Organisation.

5. Ballesteros, J., Duffy, J. C., Querejeta, I., Arino, J., \& GonzalezPinto, A. (2004). Efficacy of brief interventions for hazarous drinkers in primary caređ: systematic review and meta-analysis. Alcoholism: Clinical \& Experimental Research, 28(4), 608-618.

6. Burke, B. L., Arkowitz, H., \& Dunn, C. (2002). The efficacy of motivational interviewing and its adaptations: what we know so far. In W. R. Miller \& S. Rollnick (Eds.), Motivational Interviewing: Preparing People for Change (2nd ed., pp. 217-250). New York NY: Guilford.

7. Carey, K., Scott-Sheldon, L., Carey, M., \& DeMartini, K. (2007). Individual-level interventions to reduce college student drinking: a meta-analytic review. Addictive Behaviors, 32, 2469-2494.

8. Coulton, S., Perryman, K., Bland, M., Cassidy, P., Crawford, M., DeLuca, P., et al. (2009). Screening and brief interventions for hazardous alcohol use in accident and emergency departments: a randomised controlled trial protocol. BMC Health Services Research, 9, 114

9. Crawford, M. J., Patton, R., Touquet, R., Drummond, C., Byford, S., Barrett, B., et al. (2004). Screening and referral for brief intervention of alcohol-misusing patients in an emergency department: a pragmatic randomised controlled trial. Lancet, 364, 1334-1339.

10. Fleming, M. F., Barry, K. L., Manwell, L. B., Johnson, K., \& London, R. (1997). Brief physician advice for problem alcohol drinkers: a randomized controlled trial in community-based primary care practices. Journal of the American Medical Association, 277, 1039-1045.

11. Harvard, A., Shakeshaft, A. P., \& Sanson-Fisher, R. (2008). Systematic review and meta-analysis of strategies targeting alcohol problems in emergency departments: interventions to reduce alcohol-related injuries. Addiction, 103, 368-376.

12. Heather, N. (1995). Interpreting the evidence on brief interventions for excessive drinkers: the need for caution. Alcohol \& Alcoholism, 30, 287-296.

13. Heather, N. \& Kaner, E. (2010) (Eds.) Special Issue on Alcohol Brief Interventions: Breaking New Ground. Drug \& Alcohol Review, 29, 581-688.

14. Heather, N., Campion, P. D., Neville, R. G., \& MacCabe, D. (1987). Evaluation of a controlled drinking minimal intervention for problem drinkers in general practice (The DRAMS Scheme). Journal of the Royal College of General Practitioners, 37, 358-363.

15. Heather, N., Rollnick, S., Bell, A., \& Richmond, R. (1996). Effectiveness of brief counselling among male heavy drinkers identified on general hospital wards. Drug and Alcohol Review, 15, 29-38.

16. Holloway, A., Watson, H., Arthur, A., Starr, G., McFadyen, A., \& Mclntosh, J. (2007). The effect of brief intervention on alcohhol consumption among heavy drinkers in a general hospital setting. Addiction, 102, 1762-1770.

17. Israel, Y., Hollander, O., Sanchez-Craig, M., Booker, S., Miller, V., Gingrich, R., et al. (1996). Screening for problem drinking and counseling by the primary care physician-nurse team. Alcoholism, Clinical \& Experimental Research, 20(8), 1443-1450.

18. Kaner, E. (2010). NICE work if you can get it: development of national guidance incorporating screening and brief intervention to prevent hazardous and harmful drinking in England. Drug \& Alcohol Review, 29, 589-595.

19. Kaner, E., Bland, M., Cassidy, P., Coulton, S., Crawford, M., DeLuca, P., et al. (2009). Screening and brief interventions for hazardous and harmful alcohol use in primary care: a randomised controlled trial protocol. BMC Public Health, 9, 287.

20. Kaner, E., Dickinson, H., Beyer, F., Pienaar, E., Schlesinger, C., Campbell, F., et al. (2009). The effectiveness of brief alcohol interventions in primary care settings: a systematic review. Drug \& Alcohol Review, 28, 301-323.

21. Kaner, E., Newbury-Birch, D., \& Heather, N. (2009). Brief intervention. In P. Miller (Ed.), Evidence-based Addiction Treatment (pp. 189-213). Burlington VT: Academic Press.

22. Lundhal, B., Kunz, C., Brownell, C., Tollefson, D., \& Burke, B. (2010). A meta-analysis of motivational interviewing: twenty-five years of empirical studies. Research on Social Work Practice, 20, 137-160.

23. McQueen, J., Howe, T., Allan, L., \& Mains, D. (2009). Brief interventions for heavy alcohol users admitted to general hospital wards. Cochrane Review. Chichester: Wiley.

24. Miller, W. R., \& Rollnick, S. (1991). Motivational Interviewing: Preparing People to Change Addictive Behavior. New York NY: Guilford.

25. Miller, W. R., \& Rollnick, S. (2002). Motivational Interviewing: Preparing People for Change (2nd ed.). New York NY: Guilford.

26. Miller, W., Zweben, A., DiClemente, C., \& Rychtarik, R. (1992). Motivational Enhancement Therapy Manual: A Clinical Guide for Therapists Treating Individuals with Alcohol Abuse and Dependence. Rockville MD: Alcohol, Drug Abuse \& Mental Health Administration, US Department of Health \& Human Services

27. Moyer, A., Finney, J., Swearingen, C., \& Vergun, P. (2002). Brief Interventions for alcohol problems: a meta-analytic review of controlled investigations in treatment -seeking and nontreatment seeking populations. Addiction, 97, 279-292.

28. National Institute for Health and Clinical Excellence. (2010). Alcohol Use Disorders: Preventing the Development of Hazardous and Harmful Drinking (No. Nice Public Health Guidance 24). London: Author.

29. Newbury-Birch, D., Bland, M., Cassidy, P., Coulton, S., Deluca, P., Drummond, C., et al. (2009). Screening and brief interventions for hazardous and harmful alcohol use in probation services: a cluster randomised controlled trial protocol. BMC Public Health, 9, 418.

30. Poikolainen, K. (1999). Effectiveness of brief interventions to reduce alcohol intake in primary health care populations: a meta-analysis. Preventive Medicine, 28, 503-509.

31. Prochaska, J., \& DiClemente, C. C. (1986). Towards a comprehensive model of change. In W. Miller \& N. Heather (Eds.), Treating Addictive Behaviours: Processes of Change (pp. 3-27). New York: Plenum Press.

32. Raistrick, D., Heather, N., \& Godfrey, C. (2006). Review of the Effectiveness of Treatment for Alcohol Problems. London: National Treatment Agency.

33. Richmond, R., Heather, N., Wodak, A., Kehoe, L., \& Webster, I. (1995). Controlled evaluation of a general practice-based brief intervention for excessive drinking. Addiction, 90, 119-132.

34. Rollnick, S., Heather, N., \& Bell, A. (1992). Negotiating behaviour change in medical settings: the development of brief motivational interviewing. Journal of Mental Health, 1, 25-37.

35. Rollnick, S., Mason, P., \& Butler, C. (1999). Health Behavior Change: A Guide for Practitioners. Edinburgh: Churchill Livingstone.

36. Rollnick, S., Miller, W., \& Butler, C. (2008). Motivational Interviewing in Health Care: Helping Patients Change. New York: Guilford Press.

37. Saunders, J. B., Aasland, O. G., Babor, T. F., de la Fuente, J. R., \& Grant, M. (1993). Development of the Alcohol Use Disorders Identification Test (AUDIT):WHO Collaborative Project on Early Detection of Persons with Harmful Alcohol Consumption--II. Addiction, 88(6), 791-804.

38. Silagy, C., \& Stead, L. (2003). Physician advice for smoking cessation (Cochrane Review). Chichester: Wiley.

39. Wallace, P., Cutler, S., \& Haines, A. (1988). Randomized controlled trial of general practitioner intervention with excessive alcohol consumption. British Medical Journal, 297, 663-668. 